\title{
Rickettsia japonica
}

National Cancer Institute

\section{Source}

National Cancer Institute. Rickettsia japonica. NCI Thesaurus. Code C86722.

A species of aerobic, Gram negative, rod and cocci shaped bacteria assigned to the phylum Proteobacteria. This species is oblig ately intracellular, motile, does not form plaques in Vero cell cultures and is transmitted to humans by a tick, Haemaphysalis hystricis. R. japonica is a pathogen that causes Japanese spotted fever. 